\title{
“YILBIZ” SÖZCÜĞÜ ÜZERİNE
}

\author{
ABOUT THE WORD "YILBIZ"
}

\author{
ПРО СЛОВО «ЙЫЛБЫЗ»
}

\section{Servet ERTEKİNOĞLU*}

\section{ÖZ}

Anlamlandırmakta güçlük çekilen veya aklın kavramakta zorlandığı meseleler hakkında gizemli bir gücün varlığından sıkça dem vurulur. İlk insanlardan günümüze kadar bu değişmemiştir. Mitololojier de bu gizemli güçler etrafında şekillenmiştir. İnançları da bu güçler şekillendirmiştir. Böylece insanlar, güçlerinin yetmediği veya herhangi bir müdahalede bulunma imkânlarının olmadığı olayları bu sayede daha rahat anlamlandırır, sebebini açıklar olmuşlardır.

Türklerin yaşadıkları coğrafya itibariyle pek çok kültürle etkileşim içinde olmaları doğal olarak o kültürlerin kavramlarının dile yerleşmesi sonucunu doğurmuştur. İslâmiyet'i Farslar aracılığıyla benimseyen Türklerde namaz, oruç gibi İslâmî terimlerin de Farsça olması bu etkileşimin açık bir göstergesidir. Ancak Türklerin İslâmiyet'i kabul ettikleri ilk zamanlarda bu etkileşim zaman almıştır. Mesela Kutadgu Bilig'de Allah sözcüğünün geçmemesi, bu sözcüğün yerine Bayat, İdi, Tanrı sözcüklerinin kullanılmasının Karahanlıların müslümanlığı yeni kabulüyle ilgili bir durum olduğunu söyleyebiliriz. Ayrıca Şeytan, iblis sözcüklerinin yerine de yek sözcüğünün kullanıldığını görürüz.

İslâmiyetin kabulüyle birlikte Türkler yeni bir inanç sistemini kabul etmekle birlikte önceki yaşamlarından bazı geleneklerini bu yeni inanç sistemiyle harmanlayarak, yeni bir biçime dönüştürerek devam ettirmişlerdir. Din tarafından batıl inanışlar olarak adlandırılan bu tür davranışlar kişiler tarafından dinin bir parçası kabul edilmiş ve günümüzde de sergilenmeye devam edilmiştir. "Şeytan kulağına kurşun" deyip tahtaya üç defa vurma bunlardan biridir. Böylece nazardan sakınılacağı hesap edilmiştir. Bu yazıda Anadolu'da "Yılbız kulağına kurşun" şeklinde kullanılan bu deyimdeki yılbız sözcüğü üzerinde durulacaktır.

Anahtar Sözcükler: Yılbız, Batıl İnanışlar, Mitoloji, Anadolu, Din

\section{ABSTRACT}

We often talk about the mysterious power about the things we have difficulty understanding. This situation has not changed until today from the first people. Mythologies and beliefs have also been shaped by these mysterious forces. Thus, people have able to explained more easily the events that their power is not enough or they are not capable of any intervention.

* Yrd. Doç. Dr., Ömer Halisdemir Üniversitesi Fen Edebiyat Fakültesi Türk Dili ve Edebiyatı Bölümü, servetli@gmail.com 
Turks have to interact with many cultures in terms of the geography they live in, which naturally results in the placement of the concepts of those cultures into the language. It is a clear indication of this interaction that the Islamic terms are Persian, such as prayer and fasting in Turks who adopt Islam through Persians. But in the early times when the Turks accepted Islam, this interaction took time. For example, in Kutadgu Bilig, we can say that the use of the words Bayat, Idi, and Tanrı instead of the word of Allah is a matter of new acceptance of the Muslims of the Karahans. We can also see that the word yek is used instead of the words Şeytan, iblis.

With the acceptance of Islam, the Turks, while accepting a new belief system, maintained their tradition from their previous lives by combining this new belief system and into new form. Such behaviors, which called superstitious beliefs by religion, have been accepted as a part of religion by the people and have continued to be exhibited today. To say "touch wood (Şeytan kulağına kurşun)" and to tap the wood three times is one of them. Thus, it has thought to be protected from the evil eye. In this article, we will focus on the word "yılbız" which is used in Anatolia as "touch wood (yılbız kulağına kurşun)".

Key Words: Yılbız, Superstitious Beliefs, Mythology, Anatolia, Religion

\section{АННОТАЦИЯ}

Речь идет о таинственных силах, которых трудно объяснить словами или уму непостижимо. Это абсолютно не изменился с появления человечество. Такие тайные силы изображаются в мифологии. Таким образом, благодаря этому люди нашли в себе силу воли чтобы найти причину таких проблем.

Поскольку Турки жили в контакте со множествами культурами и в результате эти культурные понятия отражаются на их языках. Так как, Тюрки приняли ислам с помощью персов, некоторые исламско-религиозные термины как намаз, ораза взяты с персидского, это знак того, что есть влияние этих культур. Когда Тюрки приняли ислам у них не было влиянии. Например, в «Кутадгу Билике» не упоминается слово Аллах. Вместо этого используется слова Байат, Иди, Танир (Бог), потому что, Караханиды в это время только что принимали ислам. Кроме того, видим, что вместо Шайтан, Иблис использовали слова Йек (yek)

Несмотря на то что Тюрки приняли ислам, они продолжали свою жизнь согласно новой системе вероисповедания обьяденив старые жизненные обычаи с некоторыми новыми исламскими традициями. В религии такие дествии называют обрядами и некоторые люди воспринимали его как часть религии, а также по сей день использует эти понятии. Например, сказав "Şеytan kulağına kurşun" «Свинец в ухо сатаны» затем трижды стучали по дереву - один из этих действий. Таким образом, люди верили, что это сохроняет от сглаза и порчи. В данной статье рассматривается слово йылбыз, который используется в фразеологизме Анадолы «Свинец в ухо Йылбыз».

Ключевые слова: Йылбыз, обряд, мифология, Анадолы, религия.

\section{Giriş}

Anlamlandırmakta güçlük çekilen veya aklın kavramakta zorlandığı meseleler hakkında gizemli bir gücün varlığından sıkça dem vurulur. İlk insanlardan günümüze kadar bu değişmemiştir. Mitololojiler de böyle şekillenmiştir. İnançları da bu güçler şekillendirmiştir. Böylece insanlar, güçlerinin yetmediği veya herhangi bir müdahalede 
bulunma imkânlarının olmadığı olayları bu sayede daha rahat anlamlandırır, sebebini açıklar olmuşlardır. Bu manada mitoloji, tarihin milletlerin hafızasında değişmiş şekli veya yorumudur.

Türkiye'de folklor araştırmalarının artmasıyla İslâm diniyle alakası olmadığı hâlde dinden imiş gibi kabul edilen âdet ve gelenekler ortaya çıkarılmıştır. Bunların arasında eski Türk inançlarından gelen unsurlar bulunmaktadır. Zaman içinde bunlar örf ve âdetler hâline gelmiş, dinî inançlarla ilgisini kaybetmiştir (İnan, 1998: 478-479).

Türklerde eski ilâh-ruhlardan birçoklarının bugüne kadar yaşadığını görmek mümkündür. Özellikle eski Şamanlıkta devam eden Yakut, Altay ve Yenisey Türklerinde, ayrıca bin seneden beri İslâm dininde bulunan Türklerde de eski geleneklerin izlerine rastlanır (İnan, 1998: 259).

Bugün Anadolu'nun pek çok yerinde kapı eşiğinde durmanın günah olduğu inancı vardır. Büyüklerimizden sıkça duyduğumuz bu inanış aslında Şamanizmin Eşik Tanrısının biçim değiştirerek İslâmî bir değer kazanmasından başka bir şey değildir.

Türkler, yaşadıkları coğrafya itibariyle pek çok kültürle etkileşim içinde olmuşlar doğal olarak o kültürlerle kelime alışverişinde bulunmuşlardır. İslâmiyet'i Farslar aracılığıyla tanıyan Türklerde namaz, oruç gibi İslâmî terimlerin de Farsça olması bu etkileşimin açık bir göstergesidir. Konuyla ilgili Şinasi Tekin (2015: 39-40) şunları der: "İslâmiyet Sünnî İanlı Sâmânîler aracılı̆̆l ile Türklere geçer. Gene burada da bir asır süren bir hazırlık devresi, bir şifâhî dönem tekaddüm eder ilk Karahanlıca eserlere ve bu arada tabî̀ ilk Kur'an tercümesine... Kervanlara katılan gezginci hocalar, vâizler Farsça ve Türkçe bilen iki dilli din adamlarl idi ve Sâmânî merkez idaresince sistemli olarak göçebe Türkler arasına gönderiliyorlardl. Işste bu temasların neticesinde Karahanlıcaya Farsça asıllı birçok Íslâmî terim girer ve bunlar Kur'an'ın ilk Türkçe tercümesinde ve bir süre sonra faaliyet gösteren Yusuf Has Hâcib'in eserinde Türk dilinin ayrlmaz parçaları olarak yerini alır."

Bugün akidelerini bilmediğimiz eski Türk inancının izlerini dini terim olarak kullanılan bazı sözcüklerde görmek mümkündür. Bunlar, İslamî terminoloji ile birleşmiş, hatta kaynaşmış gibidir. Bunlardan bazılarının kökeninin Arapça mı Türkçe mi olduğu taştışmalıdır. Bu sözcüklerden birisi de Türkçede kullanılan albız (ilbiz, yilbiz, yelpiz, yalbız, yalpız, yılbız) ile Arapça iblis sözcükleridir.

Ahlat yöresinde "Yılbız kulağına kurşun" (Ertekinoğlu 2017: 297), Karaman yöresinde "Yelpiz kulağına kurşun" (Koraş 2002: 176), Kırşehir yöresinde "El yattı albız battı" (Koraş 2002: 176) ifadelerinde geçen yılbız/yelpiz/albız sözcükleri şeytan karşılığ1 kullanılmaktadır. Yılbız/yelpiz/albız sözcüğü bu manada incelemeye değer bir sözcüktür.

Yllbız sözcüğünün telaffuzuna yakın olması münasebetiyle iblis ve albastı sözcükleri dikkat çeker.

\section{Türk Dillerinde Albastı}

Hem eski Türk inancında hem de İslâmiyet sonrası Türk halk inanışında bugüne kadar yaşayan ve önemli bir yer tutan ruhlardan biri Al yahut Albastıdır. Bütün Türk inanışlarında aynı olan ruhtur (İnan, 1998: 259).

Türk topluluklarında Alkarısı, Albastı, Albis, Albıs, Almis, Abası, Al, Hal, Alperisi, Alanası, Alruh ve Almış gibi farklı adlarla bilinen bu kötü ruhun, genellikle lohusa kadınlara ve yeni doğmuş çocuklara musallat olduğuna inanılır. Taşıdığı yapı ve fonksiyonları ile kara iyeler zümresinden olan bu varlığın kişiliği gibi, fiziki görünümü de 
sürekli değişkenlik gösterir. (Araz, 1995: 31). Kimi Türk boylarında ise bu iye Kara Albastı ve Sarı Albastı şeklinde iki farklı iki iye olarak kabul edilir (Kalafat, 1999: 25).

Türk dillerinde "korkulu ruh, eziyet verici ruh, ev cini ve doğum sirasında zarar veren kötü ruh, yerin ve suyun ruhlarl" (İnan, 1998: 265) gibi anlamlarda kullanılan "Albastı" (Türkmen), “Albaslı" (Karakalpak, Nogay, Kumuk), “Al”, “Albıs”, Almıs”, “İlbis” (Altay; Naskali-Turanlı: 23-24; 89), "Albastı" (Karaçay, Balkar, Kazak), "Alvasti” (Uygur), "Olbostı" (Özbek), "Albarstı" (Kırgız; Yudahin 2011: 22a), "Abaahı" (Yakut; Vasiliev 1995: 254) sözcükleri vardır. Ayrıca Moğolca albin "Şeytan, iblis, kötü ruh, cin” (Lessing 1960: 28b) demektir. Bunların hepsinde "Al" ortaklığı göze çarpar.

Türklerdeki al ruhu ile ilgili Beydili'nin değerlendirmesi şöyledir: "Al, Türk halklarının demonolojik görüşlerinde geniş yer tutan su, dă̆ ve yer objeleriyle bağlanan mitolojik bir varlıktır. Bir görüşe göre ise Tanrl, Hz. Adem'i yarattığ zaman, ona arkadaş olsun diye "Al"l da yarattı. "Al", ateşten ve tek gözlü olarak yaratıldl. Adem ise etten, kandan yaratılmış bir varlıktı ve bunun için de "Al" tarafindan sevilmedi." (Beydili 2005: 43, 44).

$\mathrm{Bu}$ "al" sözcüğünün ruh, renk, hile veya ateş anlamlarından hangisiyle anlamlandırılması gerektiği tartışmalı bir konudur. Abdulkadir İnan (1998: 265) albastı kelimesinin kökeninin Sümerlerin $A l$, Alu, Alal sözcüklerinde aranması gerektiğini belirtir.

Celal Beydili albastı sözcügündeki bastı sözcüğünün, Tungus-Macar dillerinde en eski dinî mitolojik motif olarak kullanılan "Masi" olduğunu belirterek bu sözün kökünün eski Türk dillerinde aranması gerektiğini söyler. Devamında, "Şüphesiz "Albastı" adının ikinci hecesini "başll" gibi değil, ona daha yakın anlamları olan sözcüklerle açıklamak daha uygun olur. Örneğin, Akadlardaki, "Karibatu" ruh adının "batu” kısmı veya "Labastu" ruh adının "batu” kısmı yahut eski Ön Asya'da kullanılan "Bağ-maştu” adındaki "maştu”" kısmıyla açıklamak daha sağlam sonuçlar alınmasını sağlar. Bu da adın " Al Ruhu” içeriği taşıldı̆̆ fikrini perçinleyecektir. Bu bakımdan klasik Azerbaycan şairlerinden M. P. Vakıf'ın şiirindeki, "Ya hurisin ya meleksin ya basti" misrasinın, "basti” sözcügünün ruhla olan anlamdaşlığ l, böyle bir yorumun yani maştu > mastı > bastu > bastı olarak yapılan değişimin doğru olabileceğini gösteriyor." (Beydili 2005: 41) şeklinde açıklanabileceğini ifade eder.

Kubbealtı Lugatında ise söcük al "kırmızı" ve bas-mak'tan al bas-tl; isimleşmiş cümle şeklinde belirtilmiştir (Ayverdi, 2011: 38a).

\section{Yllbiz}

Her toplumda iyiliği ve kötülüğü temsil eden varlıklar söz konusudur. İslâmiyet öncesi Türklerde Şeytan, İblis gibi kötülüğü simgeleyen Erlik vardır. Tanrı olarak Erklig biçimiyle Orhon ve Yenisey yazıtlarında geçen bu sözcük çoğu araştırıcı tarafından "güçlü, kudretli olarak" anlamlandırılmıştır. Mesela Bilge Kağan yazıtında "üze tepri erklig” [Bilge Kağan Kuzey 12] biçiminde geçen cümleyi Talat Tekin "yukarıda Tanrı kudretli" diye çevirmiştir (Tekin 2010: 48-49). Potapov (2012: 300), eski Türk yazıtlarındaki Erklig'in eski Türk tanrısı olduğunu ve bunun S. G. Klyaştornıy tarafından kanıtlandığını belirtir.

Erlik, bugün Altay-Sayan Türklerinde Yeraltı Dünyası'nın baş tanrısı olarak kabul edilmektedir. Bahaeddin Ögel'e göre "Erlik”, Türk destanlarında Şeytan'ın kendisidir ve her zaman kendi istek ve yaratılışı gereğince kötü şeyleri seçer ve kötü işleri yapmayı tercih eder (Ögel 1993: 428-29). 
Bugün Altaycada kötü ruh, Şeytan anlamıyla körmös de geçer (Naskali-Duranlı 1999: $122 b)$. Sözcük gör- fiiliyle ilgili olmalıdır. Görmeyen, kör diye anlamlandırabileceğimiz bu sözcük Şeytanın karanlığını ifade eder.

Uygurların Mani dinini benimsemeleriyle birlikte bu dinde Şeytan karşılığı kullanılan yek sözcügü alınmış ve uzun bir süre varlığını sürdüren bu sözcük İslâmî etkinin yaygınlaşmasıyla birlikte yerini İblis ve Şeytana bırakmıştır.

iblis için sözlüklerde şu maddeler geçmektedir:

İblis 'Şeytan' Ar. İblis EYun. бı́́ßoגos (diábolos) a.m. G. Meyer 1893 s. 66 (Tietze 2009: 362b).

Iblis 'Şeytan’ (البل) i. (Ar. iblis < İbr.) (Kubbealt1 2011: 533a).

Iblis 'Şeytanın bir adı, Azazil' Ar. (ابليس) (Lane I 1968: 248c).

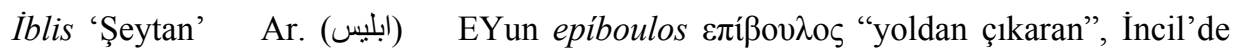

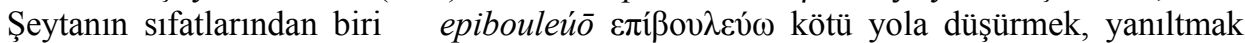

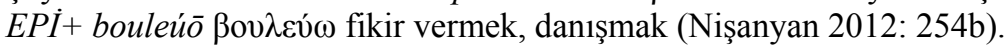

Hiçbir tarihi ve güncel kaynakta rastlamadığımız yılbız sözcüğü "Şeytan” karşılığı kullanılan "albız"dır. Albız sözcüğüne ise ilk kez Edirneli Nazmî Divânında "Şeytan" anlamiyla rastliyoruz:

Urılur zencîre albızlar kamu

Kutlulugla her kaçan irer oruç (Üst 2012: 711).

$\mathrm{Bu}$ beyitte albız-kut çatışmasından söz edebiliriz. Kut, Türklerde ilahî bir nimettir, aynı zamanda devlettir. Oruçla temas eden, kut alarak albız olmaktan kurtulmuş olur böylece

Ayrıca aynı divanda bir de albizlik geçer:

Beni ol sevdügüm yanında gördükce günisinden

Gelür aramuza girer bir albizlik ider engel (Üst 2012: 2135).

$\mathrm{Bu}$ beyitte engel rakîb demektir. Sevgili ile âşı arasına giren her şey "rakîb"dir. Bu beyitte sevgilinin davranışı albizlik olarak nitelendirilmiş, bunun sebebi de sevgilinin kıskançlı̆̆1 (günisi) olarak verilmiştir.

Yukarıdaki beyitlerde halk söyleyişi olan albız sözcüğünün geçmesi şâirin Türkî-i Basit akımının temsilcilerinden olmasıyla açıklanabilir. Şâir iblis yerine albızı tercih ederek mahallî söyleyişten yana tercihini kullanmıştır.

Tarama Sözlüğü'nde geçmeyen sözcük Derleme Sözlüğü'nde şu şekilleriyle geçer:

Albız: Şeytan (Uzunköprü-Edirne). (DS, 1993: 208b).

Elbiz: Şeytan, düşman (Gaziantep). (DS 1993: 1704b).

İlbiz (IV) [İlbis (II)] Cin, Şeytan (Bor-Niğde). (DS 1993: 2518b).

Ayrıca Hikmet Koraş tarafindan sözcükle ilgili şu tespitler yapılmıştır:

yelpiz/yalpız : 1.Şeytan, 2. örümcek ağı [Karaman/Kızıllarağini](Koraş 2002: 205).

albız: Şeytan [Kırşehir/Kaman, Sarıömerli köyü: el yattı albız battı (Koraş 2002: 178).

Yazıtlarda Şeytan anlamında herhangi bir sözcüğe rastlanmaz. Talat Tekin'in Orhon Yazıtları kitabında, Hatice Şirin'in Eski Türk Yazıtları Söz Varlığı İncelemesi adlı eserinde rastlanmayan bu sözcüğe, Erhan Aydın'ın Yenisey Yazıtları kitabında rastlamaktayız. 
Ancak Aydın (2015: 182), Kök Haya yazıtında geçen "yek enç ukug” ifadesindeki "yek" sözcügünün yazıtlar döneminde tanıklanmaması nedeniyle bu yazıtta böyle bir sözcügün varlığını kuşkuyla karşıladığını belirtir.

Uygurcada Sankritçeden ödünçleme (bk. Clauson 1972: 910a) olarak gördüğümüz yek sözcüğü Uygurca Altun Yaruk'ta genellikle yek ve birkaç kez de yik/yek içgek olarak geçer:

[yek]ning yumışçısı bir yek [Şeytanın yardımcısı bir Şeytan](Kaya 1994:65).

Keyikler adasıntın yagı yavlak yik içgekler [Geyikler tehlikesinden düşman kötü Şeytanlar] (Kaya 1994: 199).

Yavlak yek içgek... kelir kirür (Kaya 1994: 298).

-lar uguşı... kadır yavlak yek içgekler... (Kaya 1994: 296).

Yek içgek'in sıfatı olarak yavlak sözcüğü kullanılır. Bu durum Şeytanın kötülüğün sembolü olmasıyla ilgilidir. Eraslan (2012: 572a) iç-kökünden getirdiği içgek sözcügünün anlamını "kan içen, Şeytan" olarak verir. Caferoğlu (2011: 88) da sözcüğün anlamını "Şeytan, İblis, çok içen” olarak verir. Bu dönemde Şeytanın insanların kanını içen, etlerini yiyen, sürekli kötülük eden bir varlık olarak tasvir edildiği, o dönemdeki Şeytan algısının bugünkünden farklı olduğu görülür. Aynı sıfatı Kuanşi im Pusar'da da görürüz:

Yèr suvda tolu yavlaḳ yek içgek èrser kelip (KİP 29; www.derlem.cu.edu.tr).

Haustuanift'te şöyle bir ifade geçer:

Beş türlüg yäklärlügün sünüşdi (Özbay 2014: 78).

Özbay (2014: 131) buradaki beş türlü Şeytanın beş tanrının zıddı olarak Manihaizmde yer aldığını belirtir. Ben tanrı gibi beş türlü Şeytanın da beş elementi simgelediğini, bunların Duman, Kötü Ateş, Kötü Rüzgâr, Kötü Su ve Karanlık olduğunu söyler.

Uygurca Çaştani Bey Hikâyesinde ise hem yek hem de yek içkek şeklinde geçer:

Yek içkek bolsar-lar bodistv og̉uşlug [Bodistv kavmine Şeytan olacaklar] (Uigurica IV: 32/257).

Ol yme yekler yayluḳ-lar-nı̀ etin yyü [O Şeytanlar insanların etini yer.] (Uigurica IV: 14/5).

Şeytan yerine DLT'de yek (I-267), Kutadgu Bilig'de yek (3523, 3590, 3592 ...) geçer.

Karahanlı Türkçesi dönemine ait ilk Kur'an tercümesinde Arapça İblis ve Şeytan geçmez. Bu dönem bir geçiş dönemidir. Türklerin İslâmiyet’i kabulü henüz birkaç asır olmuştur ve eski kültürün izleri tamamen kaybolmamıştır. Bu nedenle o kültürden kalan yek sözcüğünün kullanımı söz konusudur. Mesela Kutadgu Bilig'de “Allah” karşılığ1 "Bayat, Tanrı, İdi” sözcüklerinin kullanılması da bu tezimizi desteklemektedir. Çünkü daha sonraki yüzyıllarda "Bayat ve İdi” sözcükleri de "yek" gibi kullanımdan düşmüşlerdir:

Armasun sizlerni İdidin yek. [“Şeytan sizi Allah'la aldatmasın”; Fatır Suresi 5. ayet

Tegürdi mânga yek emgek birle ḳın birle [“Şeytan bana bir bitkinlik ve eziyet verdi.”; Sâd Suresi 41. ayet] (Ata, 2004: 771).

Kıpçakçada da yek (CC, 117,4) geçer. Bunun yanında Kıpçak dilli bir fikıh kitabı olan İrşâdü'l-Mülûk ve's-Selâtîn'de Şeytan (Toparlı 1992: 597) ve iblis (Toparlı 1992: 535) geçerken yek geçmez. Bu durum kitapların yazıldığı sahayla ilgilidir.

Harezm Türkçesi eserlerinden Kısasü'l-Enbiyā'da İblis geçmezken hep Şeytan sözcüğü tercih edilmiştir: 
Sucal: Şeyțān mancıniḳ ḳılmaḳnı ḳayda bildi? Cevāb: Şeyț̄an mancıniḳnı tamuğda körmüş erdi...(Ata 1997: 57).

Eski Anadolu Türkçesi döneminden itibaren günümüze kadar bu sözcüğe rastlanmaz. Anadolu'da Karahanlı Türkçesinde çok sık kullanılan yek sözcüğü yerini iblis ve daha çok Şeytana bırakmıştır. Bu dönemde iblis sözcüğüne ilk kez Âşık Paşa'nın Garîbnâme adlı eserinde rastlanır:

Nitekim İblis ile Ādem-durur

Bu söze țanuḳ bular muḥkem-durur

İblise Ādem bahāne oldıdı

Ādeme İblis ḥavāle geldidi

Iblis eytdi senlüdür bu cümle iş

Senden alur ḳamu 'ālem perveriş (Yavuz 2000: 195).

Kur'an'da da belirtildiği üzere İblis Allah'a âsi olan meleğin adıdır. İblis, Hz. Âdem'e bütün meleklerin secde emrini veren Allah'a karşı gelmiş, bu nedenle huzurdan kovulmuş ve Hz. Âdem'in cennetten uzaklaştırılmasına sebep olmuştur. Yukarıdaki beyitlerde de bu İblis ile Hz. Âdem arasında geçen diyaloğa göndermede bulunulur.

Eski Anadolu Türkçesi dönemi eserlerinden biri olan İlk Kur'an Tercümesi adlı eserde yek hiç kullanılmazken Şeytan anlamında İblis bir kez geçer:

Taḥḳiḳ anlar èdindiler iblisleri dostlar Tạrı Ta āāādan özge dabı Șanurlar ["Muhakkak ki onlar Allah'tan başka Şeytanları dost edindiler.”; A’râf Suresi 30. Ayet](Küçük, 2014: 151).

Yukarıdaki tek örneğin dışında hep Şeytan ve onun bir adı olarak Iblis kullanılmıştır. Bir kez de Iblis-i la $\hat{\imath}$ in geçer:

Dab̧ı ol vaḳt ki ... şeyțān men ${ }^{c}$ oldı secdeden büyüklendi ((Küçük, 2014: 88).

...şeyțān çıkardı anları uçmak nicmetlerinden (Küçük, 2014: 89).

Lîkin İblîs râżî olmadı secde ėdicilerden olmaga Tanrı Ta âlâ eyitdi yâ İblîs-i $l a^{c} \hat{\imath} n$ niçün sen Ādem'e secde eyleyenlerile olmadun (Küçük 2014: 198).

Dede Korkut metinlerinde ise yek ve İblis geçmezken, Şeytan iki yerde geçer:

Şeytana la ${ }^{c}$ net kılduy bir suçdan ötüri (Ergin 2009b: 204).

Görklü Tayrı, sen Ādeme tac urduy, Şeytana la ${ }^{c}$ net kıldun (Ergin 2009b: 224).

\section{Sonuç}

Türkler İslâmiyeti kabul ettikten sonra şeytan için yek kullanırlar. Karahanlı sahasında da yaygın olarak kullanılan bu sözcük Anadolu sahasında hiç kullanılmamış, yerini İblis ve Şeytana bırakmıştır. Anadolu sahası yazılı metinlerinde İblis sözcügüne ilk olarak 14. yy.de rastlanırken, albız sözcüğüne en erken 15. yy.de rastlanır.

Yukarıda bahsedilenlerden hareketle şu bakış açılarının öne çıktığını söylemek mümkündür:

1. “Aslı İblis olan albız kelimesindeki değişim, dilbilimde metatez (göçüşme) olarak adlandırılır. Söyleyiş zorluklarını gidermek isteği, yabancı bir kelimenin yanlış duyulması veya başka sebeplerden meydana gelen metatezde, kelimedeki sesli ve sessizler birbirleriyle yer değiştirebilirler. Metatez örnekleri birkaç misal dışında yazı diline girememiştir. 
Metatezin oluşumunu açılayan ve her zaman geçerli fonetik kaideler bulunamamıştır." (Tietze 2002: 105a). Nişanyan (Nişanyan 2012: 16a) ve Uysal da aynı fikri desteklerler (Uysal 2012: 4-5).

2. Sümerce $A l$, Alu, Alal ve basti sözcükleri bir araya gelerek çeşitli ses değişmeleri sonucu bügünkü Türk dillerinde de kullanılan Albıs, Almıs, Illbis gibi biçimlere dönüşmüştür.

3. Arapçadaki İblis sözcüğünün Sümerce Al/Alu ile bastı sözcüklerinin birleşiminden Arapçaya geçmiş olduğu ihtimali de düşünülebilir.

4. Arapça İblis, Türkçe albız, Moğolca albin sözcükleri Sümercedeki Al, Alu sözcükleriyle ilgili olabilir.

Bize göre aynı kaynaktan gelip farklı bölgelerde benzer değişimlere uğrayan ayrı sözcükler söz konusudur. Türkçede farklı Türk topluluklarında ve yörelerde albız, elbiz, ilbiz, yalbız, yalpız, yelpiz, yılbız, Albıs, Almıs, İlbis şeklinde kullanılan sözcüklerle albastı gibi kökünde al olan alkarısl, alkarası vb. şekillerde kullanılan sözcükler ve Arapçadaki iblis kelimesinin Sümercede kötü ruhları ifade etmek için kullanılan $A l$ ve $A l u$ sözcüklerinden olma ihtimali güçlüdür. Sümercedeki al ve alu sözcükleri Arapçadaki iblis ve Türkçede çok farklı şekillerde telaffuz edilen yılbız/albız/yalbız/yelpiz/ilbiz (<albastı) sözcüklerinin kökeni olmalıdır. Arapçadaki iblis kelimesi Sümerceden Türkçeye geçmiş olan ilbis ya da albis kelimelerinin metatezle oluşmuş varyantları olmalıdır.

\section{Kisaltmalar:}

Ar. : Arapça

CC: Codex Cumanicus

DLT: Dîvânu Lugati’t-Türk

DS: Türkiye'de Halk Ağzından Derleme Sözlüğü

EYun. : Eski Yunanca

\section{KAYNAKÇA}

ARAZ, Rıfat: (1995). Harput'ta Eski Türk Inançlarl ve Halk Hekimliği. Ankara: Atatürk Kültür Dil ve Tarih Yüksek Kurumu Atatürk Kültür Merkezi Yayını No: 108.

ARGUNŞAH, Mustafa-Galip Öner: (2015). Codex Cumanicus. İstanbul: Kesit Yayınları.

Aş1k Paşa: (2000). Garipname: (Hazırlayan: Prof. Dr. Kemal Yavuz). Ankara: TDK Yayınları.

ATA, Aysu: (2004). Türkçe Illk Kur'an Tercümesi (Rylands nüshası), Karahanlı Türkçesi (Giriş-Metin-Notlar-Dizin). Ankara: TDK Yayınları.

ATA, Aysu: (1997). Ǩısä̈̈l-Enbiyā (peygamber kıssalarl). I. Giriş-Metin-Tıpkıbasım. Ankara: TDK Yayınları.

ATALAY, Besim: (2006). Divanü Lugati't-Türk (Çeviri) I-IV. Ankara: TDK Yayınları.

AYDIN, Erhan: (2015). Yenisey Yazıtları. Konya: Kömen Yayınları.

AYVERDİ, İlhan: (2011). Kubbealtı Lugatı: Asırlar Boyu Tarihî Seyri Iç̧inde Misalli Büyük Türkçe Sözlük I-III. İstanbul: Kubbealtı. (Tek cilt olarak Milliyet gazetesi tarafindan basilan eser.) 
BEYDİLİ, Celal: (2005). Türk Mitolojisi Ansiklopedik Sözlük (Çeviren: Eren Ercan). Ankara: Yurt Kitap-Yayın.

CAFEROĞLU, Ahmet: (2011). Eski Uygur Türkçesi Sözlüğü. Ankara: TDK Yayınları.

CLAUSON, Sir Gerard: (1972). An Etymological Dictionary Of Pre-ThirteenthCentury Turkish. Oxford University Press.

ÇORUHLU, Yaşar: (2011). Türk Mitolojisinin Ana Hatları. İstanbul: Kabalcı Yayınevi.

ERASLAN, Kemal: (2012). Eski Uygur Türkçesi Grameri. Ankara: TDK Yayınları.

ERGIN, Muharrem: (2009a). Dede Korkut Kitabı-1, Giriş-Metin-Faksimile. Ankara: TDK Yayınları.

ERGIN, Muharrem: (2009b). Dede Korkut Kitabl-2, Indeks-Gramer. Ankara: TDK Yayınları.

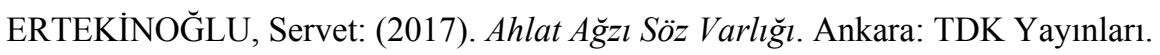

GÖKYAY, Orhan Şaik: (1973). Dedem Korkudun Kitabı. İstanbul: Milli Eğitim Basımevi.

GRONBECH, K: (1992). Kuman Lehçesi Sözlüğ̈̈, Codex Cumanicus'un Türkçe Sözlük Dizini: (Çeviren: Kemal Aytaç). Ankara: Kültür Bakanlığı Yayınları.

GÜRSOY-Naskali, Emine-Muvaffak Duranlı: (1999). Altayca-Türkçe Sözlük. Ankara: TDK Yayınları.

İNAN, Abdülkadir: (1998). Makaleler Ve Incelemeler. I. Cilt. Ankara: Türk Tarih Kurumu Yayınları. Kitabevi.

KAÇALİN, Mustafa S: (2006). Ŏguzların Diliyle Dedem Korkudun Kitabı. İstanbul:

KALAFAT, Yaşar: (1999). Doğu Anadolu'da Eski Türk İnançlarının İzleri. Ankara: Atatürk Yüksek Kurumu Atatürk Kültür Merkezi Yayını.

KAYA, Ceval: (1994). Uygurca Altun Yaruk (Giriş, Metin ve Dizin). Ankara: TDK Yayınları.

KÜÇÜK, Murat: (2014). Eski Anadolu Türkçesi Dönemine Ait Satır Arası Ilk Kur'an Tercümesi. Ankara: TDK Yayınları.

LANE, Edward William: (1968). An Arabic-English Lexicon I-VIII. Beirut-Lebanon.

MÜLLER, F.W.K: (1945). Uigurica IV: (Türkçesi: Çastani Bey Hikâyesi, S. Himran, İstanbul).

ÖGEL, Bahaeddin: (1993). Türk Mitolojisi. I. Cilt. Ankara: Türk Tarih Kurumu Basımevi.

ÖZBAY, Betül: (2014). Huastuanift Manihaist Uygurların Tövbe Duası. Ankara: TDK Yayınları.

ÖZÇELIKK, Sadettin: (2016). Dede Korkut - Dresden Nüshası - Metin, Dizin. II. Cilt. Ankara: TDK Yayınları.

POTAPOV, L.P: (2012). Altay Şamanizmi: (Çeviren: Metin Ergun). Konya: Kömen Yayınları. 
RUBEN, Walter: (2000). Eski Metinlere Göre Budizm: (Hazırlayan: Lütfü Bozkurt). İstanbul: Okyanus Yayınları.

TEKİN, Şinasi: (2015). Işstikakçının Köşesi Türk Dillerinde Sözcüklerin Ve Eklerin Hayatı Üzerine Denemeler. İstanbul: Dergâh Yayınları.

TEKİN, Talat: (2010). Orhon Yazttlart. Ankara: TDK Yayınları.

TİETZE, Andreas: (2002). Tarihi Ve Etimolojik Türkiye Türkçesi Lugatı. Cilt I A-E. İstanbul: Simurg Yayınları.

TİETZE, Andreas: (2009). Tarihi Ve Etimolojik Türkiye Türkçesi Lugatı. Cilt II F-J. Wien.

TOPARLI, Recep: (1992). İşâäü'l-Mülûk Ve's-Selâtîn. Ankara: TDK Yayınları.

UYSAL, İdris Nebi: (2012). Karaman'da Bir Yer Adı: Elbis. A.Ü. Türkiyat Araştırmaları Dergisi. Cilt: 48. s. 1-8. Erzurum.

ÜST, Sibel: (2012). Edirneli Nazmî Dîvânı. T. C. Kültür ve Turizm Bakanlığı Yayınları (e-kitap).

VARLI, M: (2008). Bidat, Hurâfe Ve Bâtıl Inançlar. İstanbul: Ensar Neşriyat Yayınları.

VASİLIEV, Yuriy: (1995). Türkçe-Sahaca (Yakutça) Sözlük. Ankara: TDK Yayınları.

YUDAHIN, K. K: (2011). Kırgız Sözlüğü. (Türkçeye Çeviren: Abdullah Aymaz). Ankara: TDK Yayınları. 